\title{
PENDEKATAN FALSAFAH SAINS AL-QUR'AN DALAM KURIKULUM PENDIDIKAN KEBANGSAAN
}

\author{
Abdul Hafiz Mat Tuah ${ }^{1}$ \& Zakaria Stapa ${ }^{2}$ \\ ${ }^{1}$ Institut Islam Hadhari \\ ${ }^{2}$ Fakultas Pengajian Islam Universiti Kebangsaan Malaysia \\ syababukm@yahoo.com.my
}

\begin{abstract}
Abstrak
Negara yang membangun seperti Malaysia masih dibelenggu dengan fenomena permasalahan pendidikan. Usaha yang dilaksanakan oleh Kementerian Pelajaran Malaysia dalam sistem pendidikan telah membawa pada tranformasi yang besar dalam kurikulum pendidikan kebangsaan. Melakukan beberapa perubahan pada sistem pendidikan perlu dilakukan bagi merealisasikan hasrat dan tujuan selaras dengan Falsafah Pendidikan Negara. Faktor ini berdasarkan pada pembentukan masyarakat masa depan akan lahir dari generasi yang terlatih dengan bentuk pendidikan masa kini. Kurikulum sekolah juga memerlukan pendekatan Sains al-Qur'an untuk melahirkan siswa yang dapat mengimbangi antara duniawi dan ukhrawi. Hal ini amat penting karena dalam kurikulum pendidikan kebangsaan ada menekankan pada aspek insan yang seimbang dan harmonis dari segi intelek, rohani, emosi, dan jasmani berdasarkan kepercayaan dan kepatuhan kepada Tuhan. Selain itu, pengaplikasian sains al-Qur'an dalam kurikulum menunjukkan bahwa sains dan al-Qur'an tidak boleh dipisahkan. Fokus kajian ini merujuk kepada falsafah sains al-Qur'an agar sains al-Qur'an dapat diterapkan dalam kurikulum pendidikan kebangsaan.
\end{abstract}

Kata kunci: Falsafah,Sains al-Qur'an, dan Kurikulum Pendidikan Kebangsaan

\section{Pendahuluan}

Pendidikan adalah suatu usaha yang akan merealisasikan pembentukan masyarakat yang bertamadun. Sistem pendidikan yang berdasarkan pada sains al-Qur'an dapat membentuk masyarakat yang baik. Sistem yang dimaksudkan ini menggunakan pendekatan pendidikan sains al-Qur'an yang menggabungkan sains sosial, sains natural dengan sains ketuhanan dalam kurikulum. Oleh karena itu, ketiga bagian ini perlu disatukan dalam kurikulum, baik pada pendidikan dasar, menengah, dan pendidikan tinggi dalam usaha memantapkan masyarakat yang akan memartabatkan ilmu tamadun (hadharah) berdasarkan Islam. Dengan demikian, penghayatan sains al-Qur'an akan melahirkan generasi ulul albab atau generasi Islam yang membangun dari pelbagai aspek keilmuan.

Usaha ini juga untuk mendukung arus kebangkitan islamisasi ilmu (Islamization of khowledge) di kalangan sarjana Islam di seluruh dunia, termasuk Malaysia. Oleh karena itu, ilmu harus digarap kembali dengan prinsip pemikiran falsafah sains al-Qur'an dalam kurikulum pendidikan kebangsaan sebagai kesinambungan ke arah mewujudkan masyarakat bertamadun yang memahami, menghayati, dan membangun ilmu secara menyeluruh dan terintegrasi. 


\section{Definisi dan Konsep Pendidikan}

Dalam bahasa Inggris, pendidikan disebut sebagai education ${ }^{1}$ yang berasal dari gabungan dua kata dalam bahasa Latin, yaitu e'ex dan ducereduc yang berarti 'memimpin'. Dari definisi tersebut dapat diinterprestasikan sebagai mengumpul informasi ke dalam diri untuk membentuk bakat.

Dalam bahasa Arab terdapat beberapa kata yang merujuk kepada makna pendidikan. Kata yang selalu digunakan antara lain ialah:

a. Tarbiyyah, berasal dari kata dasar ' $r a b b a$ ' (mengasuh, memelihara atau memimpin). Ia juga merujuk kepada proses perkembangan potensi individu, mengasuh atau mendidik untuk menuju pada satu keadaan yang nyaman dan matang. ${ }^{2}$

b. Ta'lim, berasal dari kata 'alima (mengetahui, memberitahu, melihat). Ia merujuk kepada proses menyampaikan atau menerima ilmu pengetahuan yang diperoleh melalui latihan, bimbingan atau yang lain berbentuk pengajaran.

c. Ta'dib, berasal dari kata aduba (mengetahui, berdisiplin, dan berbudaya). Ia merujuk kepada proses pembinaan watak dan pengajaran hal-hal mendasar untuk hidup bermasyarakat, termasuk memahami dan menerima prinsip yang paling mendasar sekali, yaitu keadilan.

Secara umum, ketiga istilah di atas bermakna pendidikan. Tetapi jika diteliti secara mendalam ternyata ketiga istilah memiliki makna yang berbeda. Menurut al-Attas, antara ketiga istilah tersebut, istilah $t a$ 'dib lebih tepat karena mempunyai makna yang lebih spesifik untuk menggambarkan proses pendidikan manusia

${ }^{1}$ J.A Simpson \& E.S.C. Weiner, The Oxford Enflish Dictionary, Vol 5 (Oxford: Clarendon Press, 1989).

${ }^{2}$ Mursa Muhammad Said, Fan Tabiyyah al-Aulad fi alIslam, Jld 1 (Kaherah: Dar al-Tauzi' wa al-Nashr alIslamiyyah, 2001). dibandingkan dengan istilah tarbiyyah yang mempunyai maksud yang lebih luas. Beliau memperkuat alasannya dengan mengambil contoh Rasulullah SAW yang telah menggunakan perkataan ta'dib untuk merujuk tentang pendidikan yang diberikan oleh Allah SWT kepada baginda.

Banyak definisi tentang konsep pendidikan yang telah dikemukakan oleh para ahli. Menurut Omar Hashim ${ }^{3}$, pendidikan adalah pemindahan suatu keahlian atau pengetahuan dari seorang guru kepada para muridnya. Selain itu, Hamid Reza Alavi menjelaskan pendidikan adalah satu proses pembelajaran yang bertujuan untuk melengkapkan manusia dengan pengetahuan dan keahlian yang membuatkan mereka dapat hidup lebih baik.

Tokoh falsafah Yunani juga tidak ketinggalan membicarakan pendidikan. Menurut Aristoteles, pendidikan ialah pemupukan tabiat yang terbaik dan perlu dihayati oleh seseorang supaya mereka melakukan dengan baik. Tambahnya lagi, tabiat yang paling baik ialah penggunaan akal untuk berpikir. Dengan demikian, pendidikan merupakan satu usaha untuk merealisasikan semaksimal mungkin segala potensi kebaikan yang dimiliki manusia.

Dalam konteks Islam, pendidikan merupakan satu pelajaran atau pendidikan, baik berkaitan dengan aspek kognitif, fisik, maupun rohani untuk melahirkan insan yang berperikemanusiaan. Definisi falsafah ini bertujuan untuk pembentukan individu sehingga menjadi seorang manusia yang benar-benar sempurna dari segi akhlak dan rohani. ${ }^{4}$

Berdasarkan penjelasan di atas, dapat disimpulkan bahwa pendidikan merupakan satu proses dan usaha untuk menghasilkan sesuatu, mengubah pandangan atau cara berpikir yang

\footnotetext{
${ }^{3}$ Pidato yang disampaikan dalam Kongres Pendidikan Negara pada tanggal 17 Maret 1988.

${ }^{4}$ Kurshid Ahmad, Prinsip-prinsip Pendidikan Islam (Kuala Lumpur: ABIM, 1975).
} 
seterusnya membawa kepada paradigma tingkah laku seseorang. Pendidikan merupakan proses yang berlangsung secara berkesinambungan karena tidak hanya didapat di ruang kelas saja, melainkan juga didapat dari pengalaman, pengamatan, dan ilham. Dalam konteks Islam, sumber yang paling dasar untuk pendidikan diperoleh dari al-Qur'an dan al-Sunnah.

Walau bagaimanapun, Islam tidaklah melihat pendidikan dari ruang lingkup yang sempit, ia tidak terbatas kepada pendidikan duniawi semata-mata, tetapi juga meliputi akhirat. Dalam konteks ini, Ibn Khaldun ${ }^{5}$ membagi ilmu kepada dua bagian yang utama; Pertama, ilmu yang bersifat fardhu ain yang dituntut kepada setiap orang supaya mengetahui dan mempelajarinya dengan melaksanakan tuntutan agama seperti ilmu tauhid, fiqh, akhlak, akidah, dan sebagainya. Kedua, ilmu fardhu kifayah, yaitu ilmu yang harus ada pada sekelompok orang dalam masyarakat tanpa melihat kepada individu tertentu seperti ilmu arsitektur, perdagangan, ekonomi, astronomi, dan sebagainya. Dengan demikian, pengkaji melihat perlu diterapkan ilmu sains al-Qur'an dalam kedua ilmu tersebut. Hal ini membuktikan bahwa agama Islam tidak mementingkan pencapaian intelektual yang tinggi semata-mata, namun juga perlu dilengkapi dengan ilmu sains dan al-Qur'an dalam setiap bidang agar dapat menghasilkan manusia yang cemerlang di dunia maupun di akhirat.

\section{Falsafah Pendidikan Kebangsaan}

Falsafah dapat didefinisikan sebagai pemikiran dan pandangan yang benar, rasional, dan bernas. Pemikiran ini dihasilkan dari usaha kajian secara ilmiah dan sistematik. Tujuan falsafah ialah mencari serta membuktikan kebenaran dalam kehidupan. Falsafah pendidikan yang menjadi panduan bagi sistem pendidikan di

${ }^{5}$ Ibn Khaldun, Muqadimah Ibn Khaldun, Terjemahan (Kuala Lumpur: Dewan Bahasa dan Pustaka, 1993).
Malaysia disebut dengan Falsafah Pendidikan Kebangsaan (FPK). FPK menjelaskan tujuan pendidikan untuk individu dan negara. Tujuan ini bermaksud melahirkan insan yang berilmu, berakhlak mulia, dan bertanggungjawab. Pendidikan merupakan proses mendasar dalam pembinaan insan yang baik, seimbang dan terintegrasi:

"Pendidikan di Malaysia adalah suatu usaha berterusan ke arah lebih memperkembangkan potensi individu secara menyeluruh dan bersepadu untuk melahirkan insan yang seimbang dan harmonis dari segi intelek, emosi, rohani dan jasmani berdasarkan kepada kepercayaan kepada Tuhan. Usaha ini adalah bertujuan untuk melahirkan warga negara Malaysia yang berilmu pengetahuan, berketerampilan, berakhlak mulia, bertanggungjawab dan berkeupayaan mencapai kesejahteraan diri serta memberikan sumbangan terhadap keharmonian dan kemakmuran keluarga, masyarakat dan negara".

Falsafah ini telah meletakkan dasar pendidikan yang dijalankan berdasarkan konsep pendidikan sepanjang hayat. Hal ini sejalan dengan tuntutan Islam dan matlamat Kementerian Pelajaran Malaysia (KPM) yang ingin menyediakan sumber daya manusia untuk kemajuan negara. Pembinaan bakat dapat dikembangkan melalui interaksi dengan lingkungan dan pendidikan yang berkualitas. Selain itu, terdapat juga kepercayaan manusia kepada Tuhan dan agama juga dimuatkan dalam FPK. Tujuan pendidikan adalah untuk membangun semua aspek diri manusia secara harmonis dan seimbang supaya kesepaduan fitrah diri manusia terpelihara serta mempunyai akhlak yang mulia. Di samping itu, FPK juga menekankan unsur intelektual, emosi, jasmani, dan rohani. Keempat unsur tersebut secara keseluruhan memberi pijakan kepada kekuatan daya berpikir yang kreatif serta dapat memupuk rasa kasih sayang kepada masyarakat dan Negara. ${ }^{6}$

${ }^{6}$ Kementerian Pelajaran Malaysia, Pelan Pembangunan Pelajaran 2000-2010 (Putrajaya, 2004). 


\section{Pendidikan Falsafah Sains Modern dan Sains al-Qur'an \\ Pendidikan Falsafah Sains Modern:}

Ahli sains Barat mendefinisikan sains sebagai kaedah untuk mencapai kebenaran mutlak melalui penyelidikan empiris dengan data yang dikumpulkan melalui pancaindera. Dengan kata lain, proses sains modern merupakan upaya mencari kebenaran melalui jalan rasional. Sains modern juga disebut sebagai suatu disiplin yang menilai sesuatu tinjauan dan informasi secara objektif, bukan secara subjektif seperti gerak hati atau emosi (intuisi).

Sains modern yang dipelajari oleh Barat berasal dari tamadun Islam. Dalam tamadun Islam, sains tidak terpisah dari agama karena mereka memahami falsafah sains dengan prinsip pemikiran al-Qur'an. Namun, paham rasionalisme yang menolak agama telah melahirkan sekularisme dalam sains, yaitu memisahkan sains dari agama. Ini bertentangan dengan paham Islam yang menyepadukan rasional dengan agama. ${ }^{7}$

\section{Pendidikan Falsafah Sains al-Qur'an:}

Setiap bidang ilmu dalam Islam saling melengkapi antara satu sama lain yang merujuk kepada konsep tauhid. Melalui al-Qur'an yang disampaikan oleh Rasulullah SAW, Allah SWT telah mengajarkan manusia tentang peraturan untuk hidup secara individu dan bermasyarakat. Di samping pancaindera, manusia juga dikaruniai akal pikiran yang dapat menafsirkan dan memahami sesuatu yang di luar pancaindera.

Para ahli falsafah Islam umumnya membagi ilmu kepada dua kelompok, yaitu ilmu naqli yang berdasarkan kepada wahyu, dan ilmu 'aqli berdasarkan ilmu pengetahuan. Ilmu naqli ialah ilmu yang diberikan kepada para Rasul untuk disampaikan kepada umat mereka. Ilmu ini mengandung petunjuk untuk manusia menuju ke jalan Allah SWT. Sedangkan ilmu pengetahuan

${ }^{7}$ Naufal, A.R., Al-Quran dan Sains Modern, Terjemahan (Bandung: Penerbit Husaini, 1987). ialah ilmu tentang diri manusia dan alam. Ilmu pengetahuan diperoleh manusia melalui pengalaman hidup secara jasmani, penyelidikan, dan pengkajian. ${ }^{8}$

Ilmu wahyu diwajibkan kepada setiap orang Islam untuk mempelajarinya dan digunakan sebagai pedoman dalam kehidupan. Sains berdasarkan wahyu, yaitu sains al-Qur'an menjadi tujuan penyelidikan ke arah keputusan yang menunjukkan tanda keesaan Allah SWT sebagai pencipta. Firman Allah SWT dalam surah Âli 'Imrân (3), ayat 190:

Yang bermaksud,

"Sesungguhnya dalam penciptaan langit dan bumi, dan silih bergantinya malam dan siang terdapat tanda-tanda bagi orang-orang yang berakal".

Tujuan pendidikan Islam ialah memupuk keimanan terhadap kebenaran dan kebesaran Allah SWT. Jadi, semua fakta dan penemuan ahli sains Islam ditafsirkan mengikut ketentuan ilmu al-Qur'an. Sedangkan sains dan teknologi yang berlandaskan paham materialisme bertujuan hanya untuk mencapai kemajuan dan kesempurnaan hidup manusia. Pandangan ini meletakkan sains dan teknologi berperan sebagai pengubah lingkungan alam menjadi produk kebudayaan bendawi sehingga manusia menjadi nyaman dan maju melalui kenyamanan lingkungannya. Ini bertentangan dengan konsep al-Qur'an yang melihat faktor utama perubahan sosial ialah manusia itu sendiri dan bukan saja lingkungannya. Firman Allah SWT dalam surah al-Ra'd (13), ayat 11:

Yang bermaksud,

"Bagi manusia ada malaikat-malaikat yang selalu mengikutinya bergiliran, di muka dan di belakangnya, mereka menjaganya atas perintah Allah. Sesungguhnya Allah tidak merobah keadaan sesuatu kaum sehingga

${ }^{8}$ Mehdi Golshani,The Holy Quran and the Sciences of Nature(Selangor: Academe Art \& Printing Servies, 2011). 
mereka merobah keadaan yang ada pada diri mereka sendiri. dan apabila Allah menghendaki keburukan terhadap sesuatu kaum, Maka tak ada yang dapat menolaknya; dan sekali-kali tak ada pelindung bagi mereka selain Dia”.

\section{Integrasi Sains al-Qur'an dengan Sains Modern}

Sejarah membuktikan implikasi dari mengesampingkan prinsip pemikiran sains alQur'an pada zaman pertengahan menyebabkan tamadun tersebut menjadi merosot. Pada masa itu umat Islam telah mengabaikan aplikasi prinsip alQur'an dalam pengajaran dan pembelajaran sains natural serta sains sosial. Perkembangan pemahaman Islam yang tidak komprehensif ini telah memberi dampak negatif terhadap tamadun Islam pada zaman pertengahan. Umat Islam juga tidak memberi perhatian untuk mengintegrasikan sains ketuhanan dengan sains natural dan sains sosial. $^{9}$

Konsep pendidikan yang memisahkan ilmu dengan agama menyebabkan aplikasi sains natural dan sains sosial tidak mendapat perhatian oleh sains ketuhanan. Barat telah mengambil dan mengimbangi teori sains berdasarkan prinsip alQur'an yang telah dibangun oleh ahli sains Islam untuk membentuk tamadun Barat. Zaman kegemilangan tamadun al-Qur'an ditiru oleh Barat hanya dari segi keduniaan yang bersifat materialistik dengan meninggalkan urusan akhirat. Sedangkan orang Islam tidak memberi perhatian terhadap al-Qur'an serta mempunyai pemahaman Islam yang sempit, yaitu hanya berkaitan soal ibadah khusus saja, dan mengabaikan kewajiban ibadah umum terutama dalam bidang sains. Akibatnya, umat Islam mengalami zaman kemunduran tamadun alQur'an. ${ }^{10}$

\footnotetext{
${ }^{9} \mathrm{Abu}$ Hassan Ali, Ensiklopedia Pendidikan Sains dalam al-Quran, Jld 1 (KualaLumpur: Emedia Publication, 2005). ${ }^{10}$ Sulaiman Nordin, Falsafah Sains dan Islam (Bangi: Universiti Kebangsaan Malaysia, 1993).
}

Pada dasarnya, falsafah sains al-Qur'an dalam kurikulum mempunyai keterkaitan antara tiga kategori utama ilmu yaitu; ilmu ketuhanan, ilmu sosial, dan ilmu natural yang berdasarkan prinsip al-Qur'an. Namun, ilmu ketuhanan menjadi landasan kebebasan berpikir untuk pembangunan ilmu sosial dan ilmu natural untuk memastikan manusia mengikuti peraturan yang ditetapkan oleh Allah SWT. Dengan demikian, pencapaian sains dalam kurikulum dapat mendekatkan diri manusia dengan pencipta-Nya. ${ }^{11}$

\section{Contoh Ayat al-Qur'an Berkaitan Integrasi Sains Ketuhanan, Sosial, dan Natural dalam Pendidikan}

Terdapat beberapa ayat al-Qur'an yang menunjukkan keterkaitan antara sains ketuhanan, sains sosial, dan sains natural. Firman Allah SWT:

1. Surah al-Saba' (34) ayat 10-11:

"Dan Sesungguhnya telah Kami berikan kepada Daud kurnia dari kami. (kami berfirman): "Hai gunung-gunung dan burung-burung, bertasbihlah berulang-ulang bersama Daud", dan Kami telah melunakkan besi untuknya, (yaitu) buatlah baju besi yang besar-besar dan ukurlah anyamannya; dan kerjakanlah amalan yang saleh. Sesungguhnya aku melihat apa yang kamu kerjakan”.

Ayat ini menerangkan kajian sumber daya alam, yaitu besi (sains natural) dapat diproses dengan ilmu dan teknologi menjadi bahan untuk membuat peralatan yang dimanfaatkan oleh manusia (sains sosial). Allah SWT juga menyeru manusia agar mengerjakan amal soleh dan memberi peringatan bahwa Allah SWT melihat segala perbuatan manusia (sains ketuhanan). Keterkaitan ketiga unsur ini dapat dilihat melalui peringatan Allah SWT kepada manusia supaya memastikan karunia-Nya dimanfaatkan sesuai

\footnotetext{
${ }^{11}$ Yahaya Jusohdan Azhar Muhammad,Falsafah Ilmu dalam al-Quran Ontologi, Epistemologi dan Aksiologi (Skudai: Universiti Teknologi Malaysia, 2012).
} 
peraturan yang telah ditentukan oleh hukum-Nya, baik secara individu maupun masyarakat. ${ }^{12}$

2. Surah al-A'raf (7) ayat 85:

"Dan (kami telah mengutus) kepada penduduk Madyan saudara mereka, Syu'aib. ia berkata: "Hai kaumku, sembahlah Allah, sekali-kali tidak ada Tuhan bagimu selainNya. Sesungguhnya telah datang kepadamu bukti yang nyata dari Tuhanmu. Maka sempurnakanlah takaran dan timbangan dan janganlah kamu kurangkan bagi manusia barang-barang takaran dan timbangannya, dan janganlah kamu membuat kerusakan di muka bumi sesudah Tuhan memperbaikinya. yang demikian itu lebih baik bagimu jika betul-betul kamu orang-orang yang beriman".

Ayat ini menunjukkan keimanan (sains ketuhanan) yang dapat memelihara seseorang dari sifat tidak jujur, seperti menipu dengan mengurangi takaran dan timbangan (sains sosial). Oleh karena itu, orang yang beriman menyadari bahwa menipu dalam perdagangan adalah memakan harta dengan cara yang salah akan menyebabkan dia termasuk golongan yang rugi.

\section{Surah al-Nahl (16), ayat 11-12:}

"Dia menumbuhkan bagi kamu dengan air hujan itu tanam-tanaman; zaitun, korma, anggur dan segala macam buah-buahan. Sesungguhnya pada yang demikian itu benarbenar ada tanda (kekuasaan Allah) bagi kaum yang memikirkan. Dan Dia menundukkan malam dan siang, matahari dan bulan untukmu. dan bintang-bintang itu ditundukkan (untukmu) dengan perintah-Nya. Sesungguhnya pada yang demikian itu benar-benar ada tanda-tanda (kekuasaan Allah) bagi kaum yang memahami (Nya)'”.

${ }^{12}$ Thameem Ushama,Sciences of the Quran an Analitical Study(Kuala Lumpur: Potensi Serentak Sdn. Bhd, 1998).
Ayat ini menerangkan tentang kekuasaan Allah SWT menurunkan hujan dan menyuburkan tanah yang dapat menghidupkan tanaman (sains natural). Dijelaskan juga jenis buah-buahan yang dapat dinikmati oleh manusia (sains sosial). Selain itu, Allah SWT juga menegaskan bahwa semua ini menunjukkan kebesaran Allah bagi manusia untuk berpikir, yaitu merenung dan memperhatikan (sains ketuhanan) agar manusia melakukan penelitian dan dapat memahami hukum alam sebagai tanda kekuasaan Allah SWT. ${ }^{13}$

\section{Integrasi Sains dalam Kurikulum Pendidikan Kebangsaan}

Paham rasionalisme yang menolak agama telah melahirkan sekularisme dalam sains, yaitu memisahkan sains dengan teologi. Paham ini telah mempengaruhi sistem kurikulum pendidikan seluruh dunia termasuk Malaysia melalui pengaruh kolonialisme. Ini jelas bertentangan dengan Islam yang mengintegrasikan dan meletakkan rasional di bawah panduan agama. ${ }^{14}$

Berdasarkan paham ini, sains yang berlandaskan materielisme bertujuan hanya untuk mencapai kemajuan dan kesempurnaan hidup manusia. Pengajaran sains sosial dan sains natural dipisahkan dari sains ketuhanan yang lebih mengarahkan kepada keduniaan yang bersifat materialistik dengan meninggalkan akhirat dan unsur spiritual. ${ }^{15}$

Walau bagaimanapun, gerakan ke arah mengintegrasikan telah berkembang di seluruh dunia termasuk Malaysia. Langkah perubahan kurikulum pelajaran berdasarkan kepada falsafah sains al-Qur'an telah dilakukan terutama di negara

\footnotetext{
${ }^{13}$ Najati Muhammad Uthman,Al-Quran wa'ilm alNafs(Beirut: Dar al-Syuruq, 1987).

${ }^{14}$ Abu Hassan Ali,Ensiklopedia Pendidikan Sains dalam al-Quran, Jld 1 (Kuala Lumpur: Emedia Publication, 2005).

${ }^{15}$ Osman Bakar,'Masalah Pendekatan Pengajaran Sains Islam”, Kertas Kerja dalam Seminar Bengkel Pengajaran, Pembelajaran Kursus Tamadun Islam (Pulau Pinang: Universiti Sains Malaysia, 1988).
} 
Islam dalam semua jenjang pendidikan, khususnya pendidikan dasar. Langkah ini diharapkan dapat membetulkan kembali dasar pemikiran sains modern kepada pemikiran falsafah sains al-Qur'an.

Prinsip utama yang ditekankan oleh Kementerian Pelajaran Malaysia (KPM) dalam konsep ini antara lain ialah penguasaan terhadap ilmu pengetahuan. Proses ini perlu untuk melahirkan insan seimbang dan harmonis seperti yang terdapat dalam Falsafah Pendidikan Kebangsaan (FPK). Dalam menghadapi tantangan globalisasi masa kini, faktor ilmu bersepadu, kemajuan sains dan teknologi sewajarnya menjadi fokus utama untuk melahirkan masyarakat yang bukan saja memiliki ilmu dan keterampilan, tetapi juga memiliki nilai-nilai murni yang mampu memberi sumbangan terhadap pembangunan negara, bangsa, dan agama. ${ }^{16}$

Proses mengintegrasikan ilmu sains ini sebenarnya telah dilakukan sejak beberapa dekade yang lalu ketika KPM telah menggubal kurikulum baru untuk sistem pendidikan negara. Usaha ini juga telah mendapat sambutan dari berbagai pihak. Pada jenjang pendidikan dasar dan menengah, KPM telah mencoba menerapkan idea ini dengan membendung sistem pendidikan yang masih mempunyai pengaruh dari Barat.

Dasar pendidikan kebangsaan telah dibentuk dan pelbagai langkah telah dibuat bagi mewujudkan idea ini seperti mendirikan Sekolah Menengah Tahfiz Sains (SMTS) dan pelaksanaan Kurikulum Baru Sekolah Rendah (KBSR) dan Kurikulum Baru Sekolah Menengah (KBSM) yang menekankan pada aspek integrasi ilmu. Selain itu, kurikulum Pendidikan Islam senantiasa mengalami beberapa perubahan untuk mengikuti arus perkembangan, ini sejalan dengan tuntutan sains dan teknologi terkini. Para pelajar yang belajar di sekolah agama juga tidak dipinggirkan,

${ }^{16}$ Kementerian Pelajaran Malaysia, Pembangunan Pendidikan 2001-2010 (AG Grafik Sdn. Bhd., 2001). malah didedahkan dengan kurikulum sains dan al-Qur'an. Ini memungkinkan mereka untuk menguasai kedua bidang pelajaran tersebut. ${ }^{17}$

Untuk merealisasikan konsep ini kurikulum pendidikan terutama KBSR perlu melalui satu tahap tranformasi secara menyeluruh bertujuan memberi peluang yang luas kepada guru untuk melaksanakannya secara formal. Pada tahun 2011 KPM telah membuat satu tranformasi pendidikan untuk sekolah dasar dengan menggantikan kurikulum KBSR kepada Kurikulum Standard Sekolah Rendah (KSSR). Perubahan kurikulum ini perlu dilihat secara positif untuk melahirkan para pelajar yang akan membentuk generasi hadhari pada masa mendatang. Usaha yang jitu perlu dilakukan melalui pembentukan kurikulum pelajaran yang berdasarkan pada prinsip alQur'an. Kurikulum yang berlandaskan prinsip alQur'an ialah kurikulum yang mengintegrasikan prinsip al-Qur'an dalam sukatan pelajaran dengan tujuan untuk melahirkan para pelajar yang beriman dan bertakwa. Dalam KBSR terdapat mata pelajaran yang berteraskan kepada sains ditawarkan sebagai pelajaran yang wajib dipelajari oleh setiap pelajar. Semua tahap pembelajaran ini dilihat berpotensi untuk diterapkan nilai prinsip pendidikan falsafah sains al-Qur'an.

Dalam merancang sukatan pelajaran sains, penstrukturan kurikulum perlu ada gabungan antara ilmu ketuhanan, masyarakat, dan alam sekitar. Pengaplikasian dalam masyarakat dapat meningkatkan keimanan pelajar sebagai satu wadah kebangkitan tentang kesadaran bahwa sebagai khalifah Allah SWT, kita perlu ada rasa tanggung jawab terhadap ilmu yang dipelajari agar memberi manfaat kepada diri sendiri, masyarakat, dan negara.

\section{Pelaksanaan Pada Jenjang Pendidikan}

Pada jenjang pendidikan dasar kurikulum pendidikan mengalami tranformasi dari KBSR

\footnotetext{
${ }^{17}$ Danial Zainal Abidin, Al-Quran Saintifik Meneroka Kecermelangan al-Quran daripada Teropong Sains (Kuala Lumpur: PTS Millennia Sdn. Bhd., 2009).
} 
kepada Kurikulum Standard Sekolah Rendah (KSSR). Oleh karena itu, ia mempunyai rasional bahwa pendidikan pada peringkat sekolah dasar haruslah menyeluruh dan seimbang antara perkembangan intelektual, rohani, jasmani, dan emosi. Jika kita teliti dalam KBSR ia menekankan prinsip 3M, tetapi dalam KSSR ia menekankan Prinsip 4M yaitu menulis, membaca, mengira (berhitung), dan menaakul. Ini mendorong para pelajar berpikir dengan lebih kreatif dalam pembelajarannya serta mengaitkan sains modern dengan sains al-Qur'an. Dengan kata lain, tujuan KSSR dapat membantu pelajar membentuk sikap dan perilaku berdasarkan nilai kemanusiaan yang dihargai oleh masyarakat. Selain itu, kandungan KSSR menumpukan perhatian kepada tiga aspek utama dalam pengajaran, yaitu komunikasi, manusia dan lingkungan alam serta perkembangan diri individu.

Konsep kesepaduan menaakul dalam KSSR ini sebenarnya dasar pada pengenalan kurikulum yang berdasarkan kepada falsafah sains al-Qur'an. Keberhasilan pelaksanaan KSSR amat bergantung kepada kaedah dan pendekatan yang dilakukan oleh guru dalam pengajaran mereka. Dengan demikian, isi kandungan dalam KSSR akan dapat membantu pelaksanaannya sesuai konsep kesepaduan berdasarkan pendidikan falsafah sains Islam.

\section{Contoh Penerapan nilai Sains al-Qur'an dalam Kurikulum KSSR dan KBSM}

Kurikulum KSSR meliputi mata pelajaran utama seperti Bahasa Melayu, English, Matematik, Sains, Pendidikan Islam, Pendidikan Jasmani, dan lain-lain. Ketentuan ini telah ditetapkan oleh Kementerian Pelajaran Malaysia (KPM) dengan berpandukan kepada buku teks yang telah disediakan untuk pelajar. Keseluruhan tema materi yang diajarkan dalam setiap bidang mata pelajaran ini amat sesuai khususnya dalam menyentuh bidang yang berkaitan. Walaupun demikian, isi kandungannya tidak memperlihatkan adanya kesinambungan yang mantap terhadap konsep integrasi ilmu yang berdasarkan falsafah sains al-Qur'an. Oleh karena itu, guru berkewajiban untuk memberikan penjelasan tambahan ketika proses pengajaran dan pembelajaran berlangsung.

Kandungan kurikulum seperti ini hendaklah dijadikan sebagai satu ketetapan yang terkandung dalam satu ketentuan untuk menjamin kelancaran pembelajaran di kelas. Walaupun tidak secara tertulis atau tidak dimasukkan dalam satu ketentuan, guru-guru terutama yang beragama Islam masih dapat menerapkan nilai ini dalam pengajaran mereka sewaktu memberi penjelasan. Oleh karena itu, dapatlah dinyatakan di sini bahwa bentuk dan ruang yang dapat digunakan oleh guru untuk mengajar mata pelajaran yang menerapkan nilai sains al-Qur'an dalam KSSR yaitu:

\section{Contoh dalam Pendidikan Islam}

Melalui judulmateri pembelajaran: "Mengenali Huruf Hija'iyyah". ${ }^{18}$ Judul materi ini dapat diolah dengan mengemukakan kepentingan mengetahui huruf ini karena banyak informasi yang dapat diperoleh dari kemampuan membaca dan menulis dalam tulisan Arab dan Jawi.

\section{Contoh dalam Matematik}

Melalui judul materi pembelajaran: "menggunakan kaedah: Number 0 to 10 ". ${ }^{19}$ Kandungan pelajaran seperti "I am Fuad, I am 10 years old", di sini para pelajar didedahkan dengan tahap pemikiran mereka apabila ketika umur 10 tahun. Sebagai contoh; number 1, membawa maksud kepada penjelasan singkat tentang Tuhan yang satu, yaitu Allah SWT. Selain itu, kandungan "I have 1 nose, 2 hands, 2 eyes, 10 fingers" ini dapat dikaitkan dengan kejadian manusia yang amat sempurna dijadikan oleh Allah SWT.

\footnotetext{
${ }^{18}$ Mariah Mansor, Pendidikan Islam Tahun 1 (Kuala Lumpur: Dewan Bahasa dan Pustaka, 2002).

${ }^{19}$ Wan Yusof Wan Ngah, Mathematics Year 1 (Kuala Lumpur: Dewan Bahasa dan Pustaka, 2002).
} 


\section{Contoh dalam Bahasa Melayu}

Melalui judul materi pembelajaran: "kenali diri saya". ${ }^{20}$ Materi ini dapat dikaitkan dengan konsep ta'aruf dalam Islam. Dalam alQur'an al-Hujarat ayat 13 dapat digunakan sebagai penjelasan tambahan terhadap kenapa kita perlu mengenal satu sama lain terutama dalam kehidupan di dunia ini.

\section{Contoh dalam English}

Melalui judul materi pembelajaran: "Hello". ${ }^{21}$ Dalam bab ini para pelajar akan didedahkan dengan konsep berkomunikasi dengan seseorang apabila bertemu. Mereka perlu berbicara dalam bahasa Inggris seperti "hello good morning, good evening, goodbye", dan lainlain. Ungkapan ini amat sesuai diajar kepada pelajar karena dapat dikaitkan dengan konsep salam yang dianjurkan dalam agama Islam.

\section{Contoh dalam Sains}

Melalui judul materi pembelajaran: "Parts of My Body". Dalam bab ini para pelajar akan mempelajari berkaitan dengan bagian tubuh manusia. Sebagai contoh: "I have a eyes, I have a body", dan lain-lain. Semua ungkapan ini amat sesuai untuk mengajak para pelajar mengetahui kejadian diri sebagai makhluk yang diciptakan oleh Allah SWT dengan sempurna. Sebagaimana yang dinyatakan dalam surah al-Tin (95) ayat 4; "Sesungguhnya Kami telah menciptakan manusia dalam bentuk yang sebaik-baiknya".

\section{Contoh dalam Pendidikan Jasmani}

Melalui judulmateri pembelajaran: "Kecergasan fizikal". Aktivitas ini dapat disampaikan kepada pelajar dengan lebih jelas bahwa penting melakukan pergerakan tubuh. Pergerakan ini bisa disamakan dengan pergerakan

\footnotetext{
${ }^{20}$ Zainal Arifin Yusuf, Bahasa Melayu Tahun 1 (Kuala Lumpur: Dewan Bahasa dan Pustaka, 2003).

${ }^{21}$ Zubaidah Awang, English Year 1 (Kuala Lumpur: Dewan Bahasa dan Pustaka, 2003).
}

dalam mengerjakan salat, haji, dan sebagainya. Kecergasan dituntut di dalam Islam agar mudah untuk kita melakukan ibadah.

Terdapat juga judul-judul materi ajar yang lain dalam pelajaran sekolah dasar, seperti "Animals, Plants, Light and Dark, Float or Sink". Semua materi ajar ini mempunyai keterkaitan yang erat dengan kekuasaan pencipta Allah SWT terhadap hewan, tumbuhan, dan alam semesta.

Dari contoh-contoh di atas, kita dapat kaitkan dengan ayat al-Qur'an yang mempunyai kaitan secara langsung dengan materi yang diajar:

1. Surah al-Mu'min (40), ayat 79; menjelaskan tentang kejadian hewan yang diciptakan oleh Allah SWT untuk kegunaan dan kepentingan manusiasesuai dengan materi ajar 'Animals' yang bermaksud:

"Allah SWT yang telah menjadikan hewan ternak untuk kamu, sebahagiannya untuk kamu tunggangi dan sebahagiannya untuk kamu makan".

2. Surah al-An'am (6), ayat 99; menjelaskan tentang kekuasaan Allah SWT menumbuhkan segala jenis tumbuhan sesuai dengan materi ajar 'Plants' yang bermaksud:

"Dan Dialah yang menurunkan air hujan dari langit, lalu Kami tumbuhan, maka Kami keluarkan daripada tumbuhtumbuhan itu tanaman yang menghijau itu butir yang banyak dan daripada tanaman mayang kurma mengurai tangkai-tangkai yang menjulai dan kebun-kebun anggur, dan (Kami keluarkan pula) zaitun dan delima yang serupa dan yang tidak serupa. Perhatikanlah buahnya di waktu pohonnya berbuah, dan perhatikan kematangannya. Sesungguhnya pada yang demikian itu tanda-tanda (kekuasaan Allah) bagi orang-orang yang beriman".

3. Surah al-Jathiyah (45), ayat 12; menjelaskan tentang kapal yang terapung di lautan karena kekuasaan Allah SWT sesuai dengan tajuk 
'Float or Sink' yang bermaksud:

"Allah SWT yang menundukkan lautan untukmu supaya kapal-kapal terapung serta dapat berlayar padanya dengan izinNya, dan supaya kamu dapat mencari sebahagian kurniaan-Nya dan mudahmudahan kamu bersyukur".

4. Surah Âl 'Imrân (3), ayat 190; menjelaskan pertukaran malam dan siang dengan materi ajar: 'Light and Dark'.

"Sesungguhnya dalam penciptaan langit dan bumi, dan silih bergantinya malam dan siang terdapat tanda-tanda bagi orang-orang yang berakal”.

Pada tingkat sekolah menengah terdapat juga sebagian ayat al-Qur'an menceritakan tentang kejadian penciptaan manusia dan tidak bertentangan dengan teori sains modern. Selain dari penjelasan yang terdapat dalam ketentuan yang telah ada, penerapan materi-materi ajar juga dapat diperluas dengan beberapa uraian dari aspek falsafah sains al-Qur'an. Di antara bentuk penerapan yang dapat dikaitkan dengan materi ini adalah konsep penciptaan berdasarkan al-Qur'an dan al-Sunnah, yaitu:

1. Surah al-Rahman (55), ayat 14; "Dia mencipta manusia daripada tanah kering seperti tembikar".

2. Surah al-Hijr (15), ayat 28; "Dan ketika Tuhanmu berfirman kepada Malaikat, Aku akan menciptakan seorang manusia daripda tanah kering yang berasal daripada lumpur hitam".

3. Surah al-Sajadah (32), ayat 7; "Yang membuat segala sesuatu yang Dia ciptakan sebaikbaiknya dan memulakan penciptaan manusia daripada tanah".

4. Surah al-Saffat (37), ayat 11; "Sesungguhnya Kami telah menciptakan mereka dari tanah liat".

Terdapat lagi beberapa ayat yang berkaitan dengan kejadian manusia dalam jenjang pendidikan menengah antaranya: surah Âl 'Imrân (3), ayat 59; al-Tariq (86), ayat 6; al-Mu'minun (23), ayat 12-14; al-Hajj (22), ayat 5.

Keberhasilan falsafah pendidikan yang begitu tinggi dalam KSSR dan KBSM Sebenarnya perlu banyak diterapkan dengan pengajaran berdasarkan sains dan al-Qur'an agar para pelajar memiliki pengetahuan yang berimbang antara duniawi dan ukhrawi. Selain itu, para guru juga berperan dalam menjelaskan mata pelajaran yang diajar dengan lebih kreatif. Metode dan pendekatan pengajaran memerlukan perubahan paradigma secara besar-besaran karena guru bukan hanya sebagai seorang pengajar, bahkan lebih daripada itu.

\section{Pelaksanaan Pada Jenjang Pendidikan Tinggi}

Proses merealisasikan tujuan untuk melahirkan intelektual Islam yang tulen memerlukan bangunan kurikulum sains dan teknologi berdasarkan prinsip al-Qur'an. Kurikulum yang berlandaskan kepada Islam ialah kurikulum yang mengintegrasikan prinsip al-Qur'an dalam pelajaran untuk melahirkan ilmuwan yang beriman dan bertakwa. ${ }^{22}$

Pusat pendidikan tinggi di negara Islam telah banyak yang mulai menyadari dan bangkit kembali untuk mencapai kegemilangan ilmu yang diintegrasikan dengan pendidikan Islam. Sebagai contoh Universitas Al-Azhar, banyak fakultas yang berteraskan kepada pengajian sains dan teknologi telah diwujudkan dan mendapat sambutan yang hebat oleh masyarakat Mesir. Selain itu, sebagai contoh di Malaysia, kegairahan untuk mewujudkan pengajian dan pendidikan yang berdasarkan pada pengintegrasian ilmu sains dan teknologi dengan sains ketuhanan jelas dapat diperhatikan pada mendirikan sebuah Universitas Islam Malaysia (UIM) di bawah naungan majlis raja-raja Melayu Malaysia. Tujuan pendirian UIM ini adalah untuk

\footnotetext{
${ }^{22}$ Sulaiman Nordin, Falsafah Sains dan Islam (Bangi: Universiti Kebangsaan Malaysia, 1993).
} 
melahirkan ilmuwan yang mahir dalam bidang sains dan kejuruteraan bersumberkan Islam dan al-Qur'an. Ini karena para ilmuwan di Malaysia ingin mengubah proses pengajaran yang selama ini merujuk sains Barat dan Modern kepada prinsip pemikiran sains Islam. Aspek sains ketuhanan telah digabungkan dalam pembelajaran sains sosial dan sains natural. ${ }^{23}$

Perkembangan ini merupakan sala satu perkembangan terbaru yang terdapat dalam sistem pendidikan negara Malaysia sekarang. Perkembangan yang berlaku ini sejalan dengan perkembangan pendidikan dunia Islam yang menginginkan kegemilangan falsafah sains Islam dikembalikan dan disenyawakan dalam sains sosial dan sains natural sebagaimana yang dituntut oleh Islam.

\section{Kesimpulan}

Pendidikan falsafah sains al-Qur'an menjelaskan dan menggambarkan hakikat sains yang terkandung di dalam al-Qur'an yang dapat membangun tamadun manusia sepanjang zaman. Pembinaan ilmu sains berdasarkan pada pendidikan falsafah sains al-Qur'an dapat menyelesaikan pelbagai masalah yang dihadapi oleh manusia karena penyelesaian sains al-Qur'an lebih bersifat komprehensif.

Pendidikan falsafah sains al-Qur'an dapat membentuk sistem pendidikan yang terintegrasi karena kesepaduan antara sains ketuhanan, sains sosial, dan sains natural. Oleh karena itu, sains ketuhanan menjadi landasan dalam pembentukan kemajuan dan tamadun yang dicapai oleh sains sosial dan sains natural. Kesadaran umat Islam seluruh dunia untuk merealisasikan konsep ini amat diharapkan khususnya dalam menghadapi era globalisasi. Dengan kesungguhan umat Islam, cita-cita untuk melihat keserasian prinsip pendidikan falsafah sains Islam dalam ilmu sains dan teknologi akan dapat direalisasikan sepenuhnya satu masa mendatang.

${ }^{23}$ Berita Harian, Juni 2012.
Masyarakat hari ini kian meminggirkan unsur keagamaan dan kerohanian, malah digantikan dengan unsur material dalam kehidupan mereka. Untuk mewujudkan masyarakat yang berlandaskan Islam kita memerlukan satu langkah drastis dalam kehidupan sehari-hari. Langkah ini perlu diikuti dengan tindakan yang positif dan memberi dampak. Salah satu pendekatan yang dapat diambil adalah dengan cara memartabatkan pendidikan falsafah sains al-Qur'an dalam sistem pendidikan negara. Kesadaran dan kesungguhan dari berbagai pihak, terutama umat Islam untuk merealisasikan konsep ini amat diharapkan khususnya dalam bidang pendidikan formal sekarang. Perkembangan sistem pendidikan perlu menuju ke arah konsep ini agar terbentuk generasi Islam yang membangun dari berbagai bidang yang ditekuni dan tidak memisahkan semua bentuk ilmu dangan al-Qur'an. Melalui reformasi perubahan kurikulum ini, mereka akan dibentuk berlandaskan falsafah sains al-Qur'an agar terbentuk generasi yang bertamadun.

\section{Daftar Kepustakaan}

Abdullah Muhammad Basmeih. Tafsir Pimpinan al-Rahman kepada Pengertian Al-Qur'an. Kuala Lumpur: Bahagian Hal Ehwal Islam, Jabatan Perdana Menteri, 1996.

Abu Hassan Ali. Ensiklopedia Pendidikan Sains dalam al-Qur'an. Jld 1. Kuala Lumpur: Emedia Publication, 2005.

Ahmad, Kurshid. Prinsip-prinsip Pendidikan Islam. Kuala Lumpur: ABIM., 1975.

Berita Harian. 13 Juni 2012.

Choiruddin Hadhiri. Klasifikasi Kandungan AlQur'an. Kuala Lumpur: Syarikat A. Abdul Majeed, 1996.

Danial Zainal Abidin. Al-Qur'an Saintifik Meneroka Kecermelangan al-Qur'an 
daripada Teropong Sains. Kuala Lumpur: PTS Millennia Sdn. Bhd., 2009.

Halsted, J. Mark. “An Islamic Concept of Education". In Comparative Education. Vol 40. No. 4: (Nov. 2004).

Golshani, Mehdi. The Holy Quran and the Sciences of Nature. Selangor: Academe Art \& Printing Servies, 2011.

Ibn Khaldun. Muqadimah Ibn Khaldun. Terjemahan. Kuala Lumpur: Dewan Bahasa dan Pustaka, 1993.

Kementerian Pelajaran Malaysia. 2001. Pembangunan Pendidikan 2001-2010: AG Grafik Sdn. Bhd., 2001.

Kementerian Pelajaran Malaysia. Pelan Pembangunan Pelajaran 2000-2010: Putrajaya, 2004.

Mariah Mansor. Pendidikan Islam Tahun 1. Kuala Lumpur: Dewan Bahasa dan Pustaka, 2002.

Muhammad Shadid. Metodologi al-Qur'an dalam Pendidikan. Kuala Lumpur: Penerbit Universiti Malaya, 1992.

Naufal, A.R. Al-Qur'an dan Sains Modern. Terjemahan. Bandung: Penerbit Husaini, 1987.

Osman Bakar. "Masalah Pendekatan Pengajaran Sains Islam". Kertas Kerja dalam Seminar Bengkel Pengajaran, Pembelajaran Kursus Tamadun Islam: Pulau Pinang: Universiti
Sains Malaysia, 1988.

Rahman, Fazlur. Quranic Sciences. Singapore: Pustaka National Pte. Ltd., 1981.

Said, Mursa Muhammad. Fan Tabiyyah al-Aulad fi al-Islam. Jld 1. Kaherah: Dar al-Tauzi' wa al-Nashr al-Islamiyyah, 2001.

Simpson, J.A.\& E.S.C. Weiner. The Oxford Enflish Dictionary. Vol 5. Oxford: Clarendon Press, 1989.

Sulaiman Nordin. Falsafah Sains dan Islam. Bangi: Universiti Kebangsaan Malaysia, 1993.

Thameem Ushama. Sciences of the Quran an Analitical study. Kuala Lumpur: Potensi Serentak Sdn. Bhd., 1998.

Uthman, Najati Muhammad. Al-Qur'an wa'ilm al-Nafs. Beirut: Dar al-Syuruq, 1987.

Wan Yusof Wan Ngah. Mathematics Year 1. Kuala Lumpur: Dewan Bahasa dan Pustaka, 2002.

Yahya, Harun. Al-Qur'an dan Sains. Terjemahan. Jawa Barat. Indonesia: Dzkira, 2002.

Yahaya Jusoh dan Azhar Muhammad. Falsafah Ilmu dalam al-Qur'an Ontologi, Epistemologi dan Aksiologi. Skudai: Universiti Teknologi Malaysia, 2012.

Zainal Arifin Yusuf. Bahasa Melayu Tahun 1. Kuala Lumpur: Dewan Bahasa dan Pustaka, 2003.

Zubaidah Awang. English Year 1. Kuala Lumpur: Dewan Bahasa dan Pustaka, 2003. 